\title{
Trabalho e relações sociais de sexo: uma aventura coletiva com Danièle Kergoat*
}

\section{Naira Pinheiro dos Santos **}

A obra consagrada à trajetória e produção de Danièle Kergoat, socióloga que desenvolveu importantes pesquisas $e$ conceitos no campo do trabalho e das relações sociais de sexo, mas que é também militante, professora e editora, conta com a colaboração de 29 articulistas, "membros de seu laboratório de pesquisa, ex-doutorandos/as, colegas e amigos/as de outros laboratórios e disciplinas, na França e no resto do mundo" (13). A diversidade de lugares a partir dos quais eles/as exprimem a sua homenagem já é, em si, um indicador da extensão e influência da obra de Danièle Kergoat, que não se limita ao considerável volume de publicações elencadas no último capítulo da coletânea. Sua influência, como nos permitem apreender os diversos depoimentos, é também o resultado de uma atitude metodológica, tanto quanto de uma disposição militante e de abertura teórica.

$\mathrm{O}$ respeito e o interesse pelo outro, implícitos na noção da "inseparabilidade do objeto e do sujeito na relação que o sujeito nutre com o seu 'objeto"' (88), o rigor na análise e no questionamento dos dados, a insistência com a qual procura "fazer emergir as contradições, os paradoxos, os vazios" (65), assim como a capacidade de acolher e debater suas perspectivas teóricas com colegas e orientandos/as dos mais diversos campos

\footnotetext{
* Resenha de DunezAT, Xavier, Heinen, Jacqueline, HiRATA, Helena, PFEFFERKORN, Roland. (orgs.) Travail et rapports sociaux de sexe: Rencontres autour de Danièle Kergoat. Paris, L'Harmattan, coleção Logiques Sociales, 2010. Recebida para publicação em 19 de maio de 2011, aceita em 24 de agosto de 2011.

** Doutora em Ciências da Religião/UMESP; membro do grupo de pesquisa em gênero e religião Mandrágora/Netmal. nairapinheiro@gmail.com
}

cadernos pagu (37), julho-dezembro de 2011:433-436. 
profissionais e de estudos, lhe permitiram não apenas ultrapassar fronteiras disciplinares e avançar na produção de recursos teóricometodológicos, como também estender sua influência para além de certas fronteiras geográficas e sociais. É esse processo de desbravamento teórico que vai se descortinando aos nossos olhos ao longo da obra, inclusive através dos depoimentos dos/as articulistas sobre as dificuldades e desafios que eles/as mesmos/as enfrentaram e/ou enfrentam na articulação e integração das proposições teóricas de Danièle Kergoat com os seus próprios percursos e campos de pesquisa. Fica evidente também a capacidade de transmitir o seu rigor metodológico, os seus questionamentos, de estimular e desafiar os/as colegas $e$ orientandos/as tal qual a si própria, envolvendo-os/as na "aventura coletiva que, na França e em muitos outros países, fez das relações sociais de sexo um paradigma vivo, dinâmico $e$ promissor" (14).

Por todos esses aspectos, a contribuição de Danièle Kergoat é ampla e diversificada e a presente obra procura apreendê-la a partir de sete eixos temáticos: Relações sociais de sexo, Divisão sexual do trabalho, Trabalho e subjetividade, Cruzar as disciplinas, Para além das fronteiras, Movimentos sociais e resistência, Transmitir, além de uma homenagem em forma de poema de Jacques Jenny - À guisa de epílogo - na qual apreendemos um pouco da trajetória e da história de Danièle Kergoat, e do já mencionado levantamento bibliográfico, efetuado por Françoise Pujol. $\mathrm{Na}$ introdução, os/as organizadores/as apresentam brevemente a trajetória de Danièle Kergoat como pesquisadora, destacando a sua atuação na universidade - sobretudo seu papel na estruturação de grupos de pesquisa voltados à problemática de gênero ou das relações sociais de sexo e da divisão sexual do trabalho -, bem como no campo de pesquisa propriamente dito. Destacam-se também aí alguns elementos centrais do seu trabalho de concepção teórica e que constituem objeto de debate ao longo de toda a obra. 
Contra a ideia dominante de uma classe trabalhadora homogênea, Danièle Kergoat aponta para a sua heterogeneidade, destacando, por exemplo, a condição de trabalhadores imigrantes, a importância do tempo fora do trabalho $e$ o fato de que a classe operária tem dois sexos. Com relação a este último aspecto, a contribuição de Danièle Kergoat ganha particular importância no tratamento da problemática do engajamento de mulheres operárias em sindicatos ou em ações coletivas: ela demonstra que o desejo de evitar os estereótipos sexistas em vigor, "as conduz a negar sua pertença ao sexo (social) feminino" (16). Na terceira parte do livro - Trabalho e subjetividade - questões como essa do "silogismo do sujeito sexuado feminino" - retomada por Pascale Molinier e, mais adiante por Christophe Dejours -, a das implicações psico-afetivas da divisão desigual do trabalho doméstico, assim como o debate em torno do consentimento, indicam a relevância de levar em conta a subjetividade a fim de "compreender o trabalho em toda a sua extensão" (100), como destaca Helena Hirata.

Nesse bloco, tanto quanto na segunda parte do livro Divisão sexual do trabalho - os/as articulistas dão conta do fato de que, para Danièle Kergoat, o (re)pensar a divisão sexual do trabalho implicou não apenas tratar da questão da constituição de esferas de trabalho separadas e da atribuição prioritária das atividades domésticas às mulheres, mas também em reconhecer a interpenetração entre trabalho doméstico e remunerado, inclusive no âmbito psico-afetivo, e apreender todas as implicações materiais e simbólicas de tal fato. E mais, implica na necessidade de levar igualmente em conta as relações de classe e étnico/raciais. Ela explicita aí as ideias de coextensividade - as relações sociais "interagem umas sobre as outras" (18), se reproduzem e se coproduzem mutuamente; e de consubstancialidade - as relações de dominação, exploração e opressão se entrecruzam, "estruturam juntas a totalidade do campo social" (18) -, que estão na base do conceito de relações sociais de sexo (rapports sociaux de sexe) desenvolvido por Danièle Kergoat, tema da primeira parte do 
livro. Vale a pena destacar que em francês existem as expressões relations sociales e rapports sociaux - ambas traduzidas por relações sociais em português. Para Danièle Kergoat, elas possuem significado distinto atribuindo ao primeiro termo um sentido de relação entre indivíduos, e ao segundo o de relação entre grupos sociais em posições antagônicas, concepções problematizadas por Philippe Zarifian no primeiro bloco temático.

Em todos os blocos, mas especialmente em "Cruzar as disciplinas", "Para além das fronteiras" e "Movimentos sociais e resistência" é possível constatar a amplitude da contribuição de Danièle Kergoat. Ela ultrapassa as fronteiras da sociologia conforme indicam os depoimentos e aportes de articulistas provenientes de outros horizontes disciplinares tão diversos quanto o da sociolinguística, da psicossomática, da ergonomia ou da psicopatologia do trabalho; como também geográficas - do que dão evidência as articulistas que tratam da influência de sua obra no México, no Canadá, no Brasil e na Bulgária; e sociais, uma vez que sua atuação não permanece restrita aos círculos acadêmicos, mas se conjuga à militância, estendendo sua contribuição aos movimentos sociais, de mulheres e sindicais. Em "Transmitir" trata-se do seu aporte como professora, orientadora, editora $e$ mãe.

Revelando-nos o processo e o esforço de construção e de aprendizado mútuo de perspectivas téoricas que, sem dúvida, ganharam um certo nível de evidência nos dias atuais, mas também os questionamentos e conflitos que perduram, mesmo que sob outra roupagem, a leitura dessa obra nos convida e nos estimula - a todos/as os/as "interessados/as em avançar na problemática das relações sociais de sexo, integrando o político, os movimentos sociais, as mobilizações e a resistência" (101) - a nos engajarmos nessa aventura coletiva, plena de descobertas e de desafios. 